\title{
The Effect of Corn Oil Reduction in the Diet on Laying Hen Performance
}

Author(s)

Harms RH

Russell GB

Bohnsack CR

Merkel WD

Department of Animal Sciences, University of Florida, Gainesville, FL, USA.

\section{ABSTRACT}

Hy-Line W36 hens were fed diets containing zero or $6 \%$ corn oil (CO) from 26 to $38 w k$ of age. At $38 w k$, the hens receiving the diet with $6 \% \mathrm{CO}$ were divided into three groups. One group continued to receive the diet with $6 \% \mathrm{CO}$. The level of $\mathrm{CO}$ in the diet was reduced to zero or $3 \%$ in the other two groups. The hens previously fed the diet without $\mathrm{CO}$ continued to receive the control diet. Egg weight was significantly heavier when the diet contained 6\% CO and was not significantly reduced when the level of $\mathrm{CO}$ was reduced to $3 \%$. Egg weight from control hens was significantly lower than the EW from hens that had received $\mathrm{CO}$ in the diet until $38 \mathrm{wk}$ but none thereafter. Hens fed the diet with $\mathrm{CO}$ consumed more energy than hens fed the control diet. However, when CO level was reduced to zero at 38 wk, the hens consumed less energy than hens fed the control diet. These findings indicate that the hen cannot adjust feed intake with diets based on changing energy concentration in the range from 2,783 to 3,089 $\mathrm{kcal} / \mathrm{kg}$.

\section{INTRODUCTION}

Hill et al. (1956) reported that the dietary energy content controlled the amount of feed that a hen would consume. Therefore it has been accepted for several decades that the energy content of the diet is a primary factor controlling the amount of feed the hen will eat. However, Harms et al. (2000) found that the laying hen did not recognize an increase of $10 \%$ in dietary energy when $5.963 \%$ corn oil (CO) was included in the diet. This resulted in a 7\% increase in energy intake and significantly increased egg weight (EW). Bohnsack et al. (2001) and Merkel et al. (2002) confirmed these results.

Jensen et al. (1958) were the first to report that the addition of corn oil to the diet increased EW. These workers concluded that corn oil contained an unidentified factor necessary for maximum EW. Subsequently, other workers (Shutze et al., 1958; Shutze et al., 1959; Balnave, 1971; Whitehead, 1981) concluded that the response to corn oil was due to its linoleic acid (LIN) content. However, Grobas et al. (1999) suggested that the increase in energy intake was the primary cause of the increased EW. They found no increased EW when feeding greater than $1.15 \%$ LIN, and that basal diet contained a higher level than $1.15 \%$. This also supports the conclusion that the increased EW was due to increased energy intake, and not due to increased LIN intake.

The increase in EW is desirable with young hens. However, many producers prefer that the average EW does not exceed $61 \mathrm{~g}$. Therefore, an experiment was conducted to determine the influence of removing $\mathrm{CO}$ from the diet on EW and feed consumption. 


\section{MATERIAL AND METHODS}

Three hundred twenty Hy-Line W36 ${ }^{\circledR}$ hens (36 wk of age) were used in this experiment. Four dietary treatments were fed in two separate houses. The temperature of one house was thermostatically controlled to maintain a minimum of $29.4^{\circ} \mathrm{C} \pm 1$ and it will be referred to as the warm house. The temperature of the other house was allowed to cycle from 10 to $29.4^{\circ} \mathrm{C}$ and it will be referred to as the cool house. During an 8-wk pre-experimental period, 40 hens in each house were fed the control corn soybean meal diet (Table 1). These hens received the control diet throughout the experimental period (0-0 Treatment). A hundred twenty hens in each house were fed a diet with $6 \%$ corn oil. They were divided into three groups of 40 hens. One group (6-6 Treatment) continued to get the diet with $6 \%$ corn oil. Another group was fed a diet with 3\% corn oil (6-3 Treatment). The third group was fed the control diet (6-0 Treatment). Protein, amino acids, $\mathrm{Ca}, \mathrm{P}$ and salt were increased when corn oil was added to the diet. Adjustments were made to ensure that diets would not be deficient when feed intake would be reduced, as a result of increased dietary energy. Amino acid values were based on analyses of corn and soybean meal, and the values of NRC (1994) were used for other nutrients. The hens in each group were subdivided into eight replicate groups of five individually caged hens.

The EW was measured weekly on one egg from each hen. Average EW per replicate was calculated weekly and summarized for the entire experiment. Daily egg production (EP) was recorded by hen; however, replicate averages were used. Feed consumption was measured bi-weekly, and analyzed for the entire experiment. Egg mass (EM) was calculated by multiplying EW by EP.

Data were analyzed for the six-week period using a two-way analysis of variance (SAS Institute, 1990). There was no significant interaction of house $x$ treatment for any measurement. Therefore, the data for the two houses were combined, and replicates $x$ treatment interaction were used as to test significance of the diet. Significant differences among treatments were determined by Duncan's multiple-range test (1955).

\section{RESULTS AND DISCUSSION}

Egg production (EP) was not significantly different among the four treatments (Table 2). EP was significantly higher in the cool house (92.5 vs 86.5) when the temperature of the house was allowed to cycle. The interaction between weeks and treatment was not significant $(P=0.561)$.

\begin{tabular}{|c|c|c|c|}
\hline \multirow[b]{2}{*}{ Ingredient } & \multicolumn{3}{|c|}{ Dietary Corn Oil (\%) } \\
\hline & \multicolumn{3}{|c|}{$(\%)$} \\
\hline Yellow corn & 65.35 & 59.08 & 52.83 \\
\hline Soybean meal & 24.17 & 26.89 & 29.60 \\
\hline Ground limestone & 8.32 & 8.68 & 9.03 \\
\hline Salt & 0.38 & 0.40 & 0.42 \\
\hline Vitamins $^{1}$ & 0.25 & 0.25 & 0.25 \\
\hline Minerals² & 0.25 & 0.25 & 0.25 \\
\hline Dicalcium phosphate ${ }^{3}$ & 1.17 & 1.32 & 1.48 \\
\hline DL-Methionine & 0.11 & 0.13 & 0.14 \\
\hline Corn oil & - - & 3.00 & 6.00 \\
\hline \multicolumn{4}{|c|}{ Calculated analyses $(\%)^{4}$} \\
\hline Protein & 16.63 & 17.42 & 18.20 \\
\hline Calcium & 3.49 & 3.67 & 3.84 \\
\hline Phosphorus (total) & 0.54 & 0.57 & 0.60 \\
\hline Methionine & 0.38 & 0.41 & 0.43 \\
\hline Methionine + cystine & 0.67 & 0.71 & 0.74 \\
\hline Lysine & 0.87 & 0.93 & 0.99 \\
\hline Linoleic acid & 1.29 & 3.01 & 4.71 \\
\hline Energy (kcal ME/kg) & 2,783 & 2,936 & 3,089 \\
\hline \multicolumn{4}{|c|}{$\begin{array}{l}1 \text { - Supplied per kilogram of diet: biotin } 0.2 \mathrm{mg} \text {; choline, } 500 \mathrm{mg} \text {; } \\
\text { ethoxyquin, } 65 \mathrm{mg} \text {; folic acid, } 1 \mathrm{mg} \text {; niacin, } 60 \mathrm{mg} \text {; pantothenic acid, } \\
15 \mathrm{mg} \text {; pyridoxine, } 5 \mathrm{mg} \text {; riboflavin, } 5 \mathrm{mg} \text {; thiamin, } 3 \mathrm{mg} \text {; vitamin } \mathrm{A} \text {, } \\
8,000 \mathrm{IU} \text {; vitamin B12, } 0.02 \mathrm{mg} \text {; cholecalciferol, 2,200 IU; vitamin } \mathrm{K}, 2 \\
\text { mg; vitamin E, } 20 \mathrm{mg} .2 \text { - Supplied per kilogram of diet; copper: } 10 \\
\text { mg; ethoxyquin, } 65 \mathrm{mg} \text {; iodine, } 2 \mathrm{mg} \text {; iron, } 60 \mathrm{mg} \text {; manganese, } 90 \\
\text { mg; selenium, } 0.2 \mathrm{mg} \text {; zinc, } 80 \mathrm{mg} .3 \text { - Contains } 18.5 \% \text { P and } 21 \% \\
\text { Ca. } 4 \text { - Amino acid content is based on analysis of corn and soybean } \\
\text { meal. Other nutrients were based on NRC (1994) values. }\end{array}$} \\
\hline
\end{tabular}

Table 2 - Egg production, egg mass and energy per gram egg mass when hens fed diets with different levels of corn oil.

\begin{tabular}{|c|c|c|c|c|}
\hline \multirow{2}{*}{\multicolumn{2}{|c|}{$\begin{array}{l}\text { Dietary Treatment } \\
\text { Pre-Experimental } \\
\text { Experimental }\end{array}$}} & \multicolumn{2}{|c|}{ Egg } & \multirow{2}{*}{$\begin{array}{l}\text { Energy/ } \\
\text { Egg Mass }\end{array}$} \\
\hline & & Production & Mass & \\
\hline \multicolumn{2}{|c|}{ (\% Corn Oil $\left.{ }^{1}\right)$} & $(\%)$ & (g) & (kcal/g) \\
\hline 0 & 0 & $88.6^{a}$ & $52.7^{b}$ & $5.10^{a}$ \\
\hline 6 & 6 & $89.9^{a}$ & $55.8^{a}$ & $5.02^{a}$ \\
\hline 6 & 3 & $90.3^{a}$ & $55.6^{a}$ & $4.89^{b}$ \\
\hline 6 & 0 & $89.2^{a}$ & $53.7^{b}$ & $4.74^{b}$ \\
\hline
\end{tabular}

Hens on the 6-6 and 6-3 treatments produced an egg mass (EM) that was significantly heavier than EM from hens on the other two treatments (Table 2). 
Besides, there was no significant difference in EM between the hens on the control and the 6-0 treatment. The difference in EM among treatments was primarily due to differences in EW. The EM was significantly higher in the cool house (57.3 vs 51.6g). Treatment $x$ weeks interaction was not significant $(P=0.30)$.

Egg weight (EW) from hens fed the 6-6 or 6-3 treatments was significantly higher than EW from hens on the other two treatments (Table 3). There was a gradual increase in EW during the last three weeks of the experiment. This resulted in a significant week $x$ treatment interaction. Egg weight was significantly higher (61.9 vs 59.7g) in the cool house.

Table 3 - Egg weights from hens fed diets with different levels of corn oil.

\begin{tabular}{|c|c|c|c|c|c|c|c|c|}
\hline \multirow{3}{*}{\multicolumn{2}{|c|}{$\begin{array}{l}\text { Dietary Treatment } \\
\text { Pre-experimental } \\
\text { Experimental } \\
\text { (\% Corn Oil') }\end{array}$}} & \multicolumn{7}{|c|}{ Week } \\
\hline & & $\overline{1}$ & 2 & 3 & 4 & 5 & 6 & $\overline{A v}$ \\
\hline & & \multicolumn{7}{|c|}{ (g) } \\
\hline 0 & 0 & 58.6 & 59.1 & 59.5 & 59.2 & 59.7 & 60.1 & $59.4^{c}$ \\
\hline 6 & 6 & 60.8 & 61.6 & 62.4 & 62.2 & 63.1 & 62.2 & $62.1^{\circ}$ \\
\hline 6 & 3 & 60.9 & 61.2 & 61.6 & 61.5 & 61.9 & 62.2 & $61.6^{a}$ \\
\hline 6 & 0 & 60.8 & 59.7 & 59.1 & 60.2 & 60.1 & 60.7 & $60.1^{b}$ \\
\hline \multicolumn{2}{|c|}{ Average } & $60.3^{b}$ & $60.4^{b}$ & $60.7^{\mathrm{ab}}$ & $60.8^{a b}$ & $61.2^{a}$ & $61.3^{a}$ & \\
\hline
\end{tabular}

Feed consumption (FC) was significantly greater for hens on the control treatment than for hens on the other three treatments (Table 4). The hens on the 6-6 treatment consumed significantly less feed than hens on the 6-3 treatment, and FC for hens on the 6-0 treatment was not significantly different from either of these. FC was significantly higher in the cool house (91.1 vs $86.7 \mathrm{~g})$. The interaction of treatment $x$ week was significant $(P=0.002)$. This was a result of decrease in $F C$ during the first two weeks followed by an increase in FC for the 6-3 treatment. Furthermore, FC was extremely low during the first four weeks followed by a large increase during weeks 5 and 6 for treatment 6-0.

Energy intake (EI) for hens fed the 6-6 treatment was significantly greater than the El for the hens receiving the other three treatments (Table 5). There was no difference in $\mathrm{El}$ for hens fed the control diet and the 6-3 treatment. The hens receiving the 6-0 treatment had the lowest $\mathrm{El}$. The interaction between treatment and weeks was significant $(P=0.0029)$. This was a result of decreases in energy intake during the first two weeks for hens on the 6-3 and 6-0 treatments.
This decrease was followed by an increase in El during the next four weeks for hens on the 6-3 treatment and an increase in El for hens on the 6-0 treatment at weeks 5 and 6 . The El was essentially the same throughout the experiment for hens on the control, significantly different from groups 6-0 and 6-6 (Table 5 ). Energy intake was significantly higher for hens in the cool house than for hens in the warm house (287 vs $251 \mathrm{kcal} \mathrm{ME)}$.

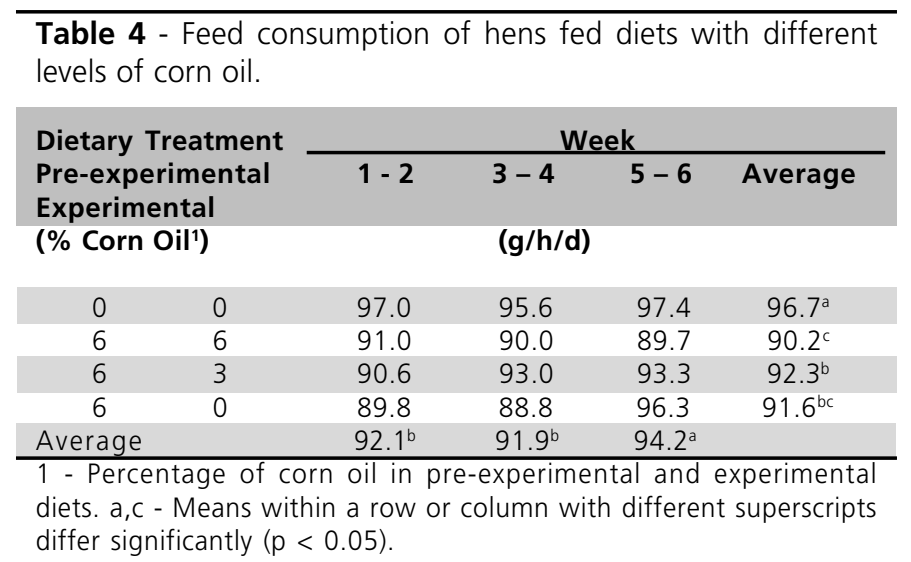
Table $\mathbf{5}$ - Energy intake of hens fed diets with different levels of
corn oil.

\begin{tabular}{|c|c|c|c|c|c|}
\hline \multirow{3}{*}{\multicolumn{2}{|c|}{$\begin{array}{l}\text { Dietary Treatment } \\
\text { Pre-experimental } \\
\text { Experimental } \\
(\% \text { Corn Oil') }\end{array}$}} & \multicolumn{4}{|c|}{ Week } \\
\hline & & $1-2$ & $3-4$ & $5-6$ & Average \\
\hline & & \multicolumn{4}{|c|}{ (kcal ME/h/d) } \\
\hline 0 & 0 & 270 & 266 & 271 & $269^{b}$ \\
\hline 6 & 6 & 281 & 278 & 281 & $280^{a}$ \\
\hline 6 & 3 & 266 & 273 & 274 & $271^{b}$ \\
\hline 6 & 0 & 250 & 247 & 268 & $255^{c}$ \\
\hline Averag & & $267^{b}$ & $266^{b}$ & $274^{a}$ & \\
\hline
\end{tabular}

1 - Percentage of corn oil in pre-experimental and experimental diets. a,c - Means within a row or column with different superscripts differ significantly $(p<0.05)$.

Hens fed the 6-3 and 6-0 treatments produced one $g$ of $E M$ with less ME/hen/day than hens on the other two treatments. (Table 2). There was no difference in energy per $\mathrm{g}$ EM between the 6-3 and 6-0 treatments. There was no difference in energy per $g$ EM for hens on the $0-0$ and 6-6 treatments.

The hens in the present experiment did not adjust feed intake when energy was reduced from 3,089 (6\% corn oil) to 2,783 (control) kcal ME/kg. This resulted in EW being reduced from 61.6 to $59.7 \mathrm{~g}$ by the end of the second week after the corn oil diet was changed to the control diet. Reduction in energy intake when corn oil was removed from the feed indicates the lack 
of the ability to adjust for energy needs. In a previous experiment (Harms et al., 2000), EW was not different for hens fed the low- and medium-energy diet. However, EW from hens fed the high-energy diet, containing corn oil, was significantly heavier than the EW from the other two groups. Energy intake was not significantly different for hens fed the low- and medium-energy diet. However, the energy intake was significantly higher for hens fed the higher energy diet. This indicates that hens were able to adjust for the decrease in dietary energy from 2,798 to 2,519 kcal $\mathrm{ME} / \mathrm{kg}$. However, they did not adjust energy intake when the energy was increased from 2,798 to 3,089 $\mathrm{kcal} \mathrm{ME} / \mathrm{kg}$.

\section{CONCLUSIONS}

Feeding a diet with $6 \%$ corn oil produced a $2.7 \mathrm{~g}$ increase in egg weight. The increased egg weight is a result of the hen not adjusting feed intake when the energy of the diet is increased. Hence, hens fed diets containing higher energy levels increased energy consumption.

Removal of corn oil from the diet resulted in a decrease in energy intake and a decreased egg weight.

The hens in the 6-0 and 6-3 treatments gradually increased feed intake, which was equal to hens fed control treatment at the end of four weeks. Previous studies have shown that corn oil can be added to the diet to increase egg weight. Present data indicate that when eggs are too heavy, corn oil can be removed from the diet and egg weight will be reduced.

\section{REFERENCES}

Balnave D. Response of laying hens to dietary supplementation with energetic equivalent amounts of maize starch or maize oil. Journal Science Food Agriculture 1971; 22:125-128.

Bohnsack CR, Harms RH, Merkel WD, Russell GB. Performance of commercial layers when fed diets with four levels of corn oil or poultry fat. Journal of Applied Poultry Research 2001; 11:68-46.

Duncan DB. Multiple range and multiple F test. Biometrics 1955; $11: 1-42$

Grobas S, Mendez J, DeBlas C, Mateos GG. Laying hen productivity as affected by energy, supplemental fat, and linoleic acid of the diet. Poultry Science 1999; 78:1542-1551.

Harms RH, Russell GB, Sloan DR. Performance of four strains of commercial layers with major changes in dietary energy. Journal of Applied Poultry Research 2000; 9:535-541.
Hill FW, Anderson DL, Danky LM. Studies of the energy requirements of chickens 3. The effect of dietary energy level on the rate and gross efficiency of egg production. Poultry Science 1956; 35:5459.

Jensen LS, Albred JB, McGinnis J. Evidence for an unidentified factor necessary for maximum egg weight in chickens. Journal of Nutrition $1958 ; 65: 219-223$

Merkel WD, Harms RH, Russell GB. Performance of commercial layers when fed diets with corn oil added from 24 to 36 weeks of age. Journal of Applied Poultry Science 2002;11:418-423.

National Research Council. Nutrient requirements of poultry. $9^{\text {th }}$ ed. Washington (DC): National Academy Press; 1994. p. 155.

SAS Institute. SAS Users Guide: Statistics. Cary (NC); 1990.

Shutze JV, Jensen LS, McGinnis J. Accelerated increase in egg weight of young pullets fed practical diets supplemented with corn oil. Poultry Science 1958; 41: 1846-1851.

Shutze JV, Jensen LS, McGinnis J. Further studies on unidentified nutritional factors affecting egg size. Poultry Science 1959; 38:1246. (Abstract)

Whithead $C$. The response of egg weight to the inclusion of vegetable oil and linolic acid in the diet of laying hens. British Poultry Science 1981; 22:525-532. 